\title{
Analysis of gas exchange in trees of the Caatinga, Brazil
}

In the Brazilian semiarid region, the high temperatures in association with the high level of solar radiation and variations in the concentration of $\mathrm{CO} 2$ which of focus on plants may influence the physical conformation of vegetables and their growth. On the basis of the above, the objective of this work to evaluate the content of gas exchange and chlorophyll in plants typical of Caatinga, associating possible interference of the power plant Borborema thermal S/A. the study carried out in the period of 2014-2018 with botanical species in two areas of the caatinga of Paraiba. To analyze the variables used the infra Red Gas Analyzer (RGA) and the SPAD. In using SPAD equipment it was found that the species had higher SPAD value were Aspidosperma pyrifolium Mart., (SPAD=50) P300. As the analyzes of gas exchange by the LCprot, obtained greater record in plant Aspidosperma pyrifolium Mart. In point (P400). The maximum values of $\mathrm{E}$ and points were recorded (P600) $\left(E=3.44>335 \mathrm{mmol} . \mathrm{H} 2 \mathrm{O} . \mathrm{m}^{-2} . \mathrm{s}^{-1}\right)$ and (P100) $\left(\mathrm{E}=3.16 \mathrm{mmol} . \mathrm{H} 2 \mathrm{O} . \mathrm{m}^{-2} . \mathrm{s}^{-1}\right)$, both second collection. The first collection the highest registered was $\mathrm{E}=2.30 \mathrm{mmol} . \mathrm{H} 2 \mathrm{O} \cdot \mathrm{m}^{-2} \mathrm{~s}^{-1}(\mathrm{P} 600)$, Ziziphus species Joazeiro. In relation of the Tukey test, it was found that the transpiration of tree species, were higher in the second collection, the range of confidence $(a, b)$ were significantly different. It was concluded that the indexes were higher by SPAD the occasion of the $2^{a}$ collection. The Ci presented low variation between the two periods. It was so, a non-correlation between the collections and areas surveyed.

Keywords: IRGA; SPAD; Photosynthesis; Perspiration; Semiarid.

\section{Análise das trocas gasosas em árvores da Caatinga, Brasil}

\begin{abstract}
Na região semiárida brasileira, as altas temperaturas associadas ao alto nível de radiação solar e as variações na concentração de CO2 que se concentram nas plantas podem influenciar a conformação física dos vegetais e seu crescimento. Com base no exposto, o objetivo deste trabalho é avaliar o conteúdo de trocas gasosas e clorofila em usinas típicas da Caatinga, associando possível interferência da usina termelétrica Borborema S / A. o estudo realizado no período de 2014 a 2018 com espécies botânicas em duas áreas da caatinga da Paraíba. Para analisar as variáveis utilizadas, o analisador infravermelho de gases (RGA) e o SPAD. Ao usar o equipamento SPAD, verificou-se que as espécies com maior valor de SPAD foram Aspidosperma pyrifolium Mart., (SPAD = 50) P300. Conforme as análises de trocas gasosas pelo LCpro +, obteve maior registro na planta Aspidosperma pyrifolium Mart. No ponto (P400). Os valores máximos de E pontos foram registrados (P600) $\left(E=3,44>335 \mathrm{mmol} . \mathrm{H} 2 \mathrm{O} . \mathrm{m}^{-2} . \mathrm{s}^{-1}\right)$ e $(\mathrm{P} 100)\left(E=3,16 \mathrm{mmol} . \mathrm{H} 2 \mathrm{O} . \mathrm{m}^{-2} . \mathrm{s}^{-1}\right)$, ambas segunda coleção. A primeira coleção mais alta registrada foi $E=$ 2,30mmol.H2O.m- ${ }^{2} \cdot \mathrm{s}^{-1}$ (P600), espécie de Ziziphus Joazeiro. Em relação ao teste de Tukey, verificou-se que a transpiração das espécies arbóreas foi maior na segunda coleta, o intervalo de confiança $(a, b)$ foi significativamente diferente. Concluiu-se que os índices foram mais altos pelo SPAD na ocasião da $2^{a}$ coleta. $O \mathrm{Ci}$ apresentou baixa variação entre os dois períodos. Foi assim, uma não correlação entre as coleções e as áreas pesquisadas.
\end{abstract}

Palavras-chave: IRGA; SPAD; Fotossíntese; Transpiração; Semiárido.

Topic: Ciências Florestais

Reviewed anonymously in the process of blind peer
Received: 02/06/2019

Approved: 04/07/2019
Joaci dos Santos Cerqueira (iD)

Universidade Federal de Campina Grande, Brasil

http://lattes.cnpq.br/4470582307237189

http://orcid.org/0000-0002-0109-3849

cerq2006@gmail.com

Helder Neves de Albuquerque (iD

Universidade Federal de Campina Grande, Brasil

http://lattes.cnpq.br/1316763030688970

http://orcid.org/0000-0002-5076-3060

helderbiologo@gmail.com

Mário Luiz Farias Cavalcanti

Universidade Federal da Paraíba, Brasil

http://lattes.cnpq.br/1805345433854856

http://orcid.org/0000-0002-9505-417X

mariolfcavalcanti@yahoo.com.br
Francisco de Assis Salviano de Sousa

Universidade Federal de Campina Grande, Brasil

http://lattes.cnpq.br/5392432872592612

http://orcid.org/0000-0002-4085-0785

fsouza2011@gmail.com
Referencing this:

CERQUEIRA, J. S.; ALBUQUERQUE, H. N.; CAVALCANTI, M. L. F.; SOUSA, F. A. S.. Analysis of gas exchange in trees of the Caatinga, Brazil. Revista Ibero Americana de Ciências-Ambientais, v.10, n.4, p.21-35, 2019. DOI: http://doi.org/10.6008/CBPC2179-6858.2019.004.0003

DOI: 10.6008/CBPC2179-6858.2019.004.0003 


\section{INTRODUCTION}

The northeastern Brazilian region is inserted in the semiarid tropical and characterized by sandy soils shallow, high annual average temperature and high losses of water in the soil by evaporation process, In addition to these physiographic characteristics, pluviometric regime prevails over a short period of months, with high interannual variability and presence of plants adapted to semiarid climate conditions (NOBRE et al., 2011).

The deciduous species of this region, during periods of hydric scarcity, reduce the area of transpiration through the loss of leaves and maintain high photosynthetic rates during the rainy season. The anatomical structures that aid in the hydric efficiency of these plants are many important for their survival (BARROS et al., 2013).

Therefore, the hydrological cycle in forest environments is dependent on factors such as rainfall, interception of canopy water, lateral flow, deep drainage and evapotranspiration (QUEIROZ et al., 2013). With the exception of precipitation, the other processes are influenced by density, by soil type, by the physiological behavior of the botanical species (OLIVEIRA et al., 2008). Thus, forests, among other functions, are of great importance for improving the landscape and shelter wildlife species, preventing erosive processes and maintaining groundwater for the hydrological cycle (BALBINOT et al., 2008).

In this way, the characteristic vegetative growth flows occur as a function of the seasons of the year and are related to variations in the photosynthesis rate and even the daily course of environmental fluctuations (light, temperature, among others) around the plant (ANTUNES JÚNIOR et al., 2011). As for the process of photosynthesis and plant transpiration, the leaves play a fundamental role, since these processes demand a large amount of water. being that, In the dry season, the caatinga plants lose their leaves as an adaptive mechanism to hydric stress (COSTA et al., 2010).

On the functioning of the stomata and the leaf area, it is observed that they directly influence the productivity of the plant, being the stomata controlling the absorption of Carbon dioxide $\left(\mathrm{CO}_{2}\right)$ and leaf area determines the interception of light (COSTA et al., 2007). Thus, high temperatures, inherent to the Brazilian semiarid region, coupled with the high solar radiation index and the variations in $\mathrm{CO}_{2}$ concentration on the plants may influence the physical conformation of the plants, reflecting its growth (BELTRÃO et al., 2008).

According to their photosynthetic metabolism plants can be divided into 3 large groups, C3 plants, C4 plants and CAM plants. Since the C3 group are those whose first product is phosphoglyceric acid or gluconate, a compound with 3 carbons, which only have the enzyme RuBisCO, belonging to the Calvin Cycle as an alternative for carbon fixation. This group occurs in approximately $85 \%$ of the dominant plant species in the terrestrial ecosystems, being the natural vegetation of tropical forests, temperate regions and high altitude almost exclusively C3 (MENDONÇA et al., 2010; PINTO et al., 2006).

The increase in the concentration of atmospheric $\mathrm{CO}_{2}$ also increases the photosynthetic rate in the plants, being this process immediately limited due to the greater consumption of Rubisco and energy, which are not supplied at the same speed. As for acclimatization, the high concentrations of $\mathrm{CO}_{2}$ in the atmosphere 
consist of a series of alterations in its plant metabolism, at different levels of organization, ranging from molecular and biochemical changes to anatomical and morphological (WALTER et al., 2015).

It is still outstanding, that among anthropic interventions floristic species are more sensitive to pollution than animals, including humans. In this sense, it has been observed in plants exposed to atmospheric pollutants the decrease of the intercellular spaces of the leaves, which hinders the displacement of phytotoxic compounds in plant tissues (ALVES et al., 2001). Based on the above, the objective of this work was to evaluate the chlorophyll content and the gas exchange in plants typical of the Caatinga, associating possible interference of the Thermoelectric Power Plant Borborema S.A..

\section{MATERIAL AND METHODS}

\section{Characterization of the study area}

This research was the result of the Doctoral Thesis on Natural Resources of the Federal University of Campina Grande (UFCG), Paraíba, Brazil, during the period 2014-2018. Its primary importance is that it treats a study with botanical species of the Caatinga in two areas. Area 1, the surroundings of Borborema Energetic S.A Thermal Power Plant, is located at coordinates $7^{\circ} 17^{\prime} 47.49^{\prime \prime} S$ e $35^{\circ} 54^{\prime} 34.41^{\prime \prime O}$; already area 2 , it is located at the coordinates $7^{\circ} 16^{\prime} 36.25^{\prime \prime} \mathrm{S}$ e $35^{\circ} 52^{\prime} 54.23 " \mathrm{O}$, located at $2200 \mathrm{~m}$, East of the Thermoelectric Plant (UTE) (figure 1). The study in area 2 was set up as an experimental area (control). For didactic and statistical purposes, the points (P100 to P500) and Area 2, point P600 were adopted for Area 1. The same methodological procedures were applied in both areas.

In the study areas average annual temperatures are recorded between 22 and $26^{\circ} \mathrm{C}$, with an average annual rainfall of $700 \mathrm{~mm}$, rainy season from April to September, relative air humidity between 60 and $80 \%$ and average atmospheric pressure around $950 \mathrm{hPa}$, with small annual amplitude due to small temperature variations (AZEVEDO et al., 2015; BRASIL, 2010; MACEDO et al., 2011; SOUZA et al., 2006).

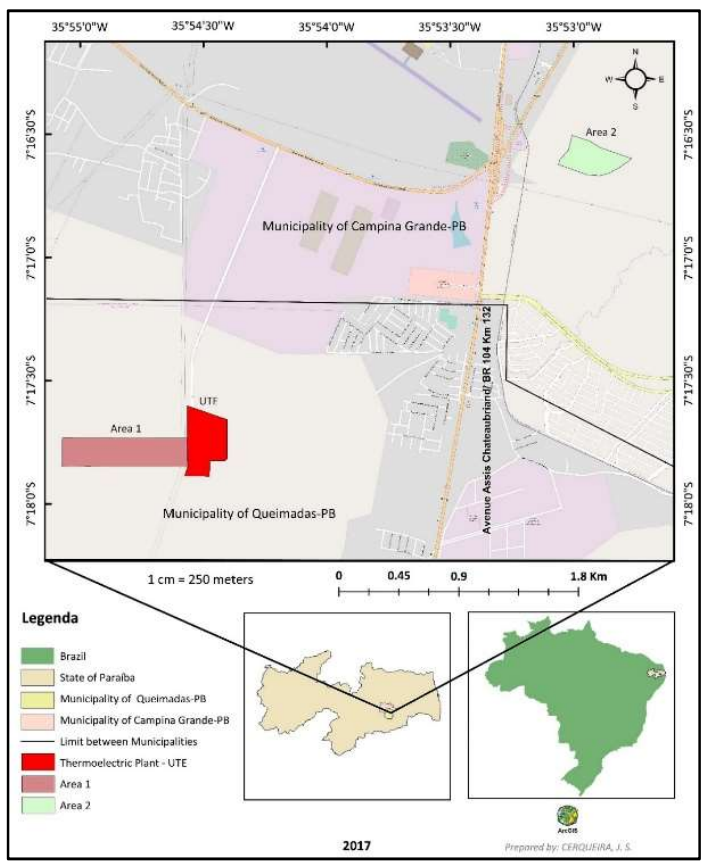

Figure 1: Areas researched with botanical species of the Caatinga in Campina Grande (PB). 


\section{Identification and evaluation of flora gas exchange}

For the delimitation of the sample area we used GPS Garmin Gpsmap 62sc 5mp camera, satellite images, trenas, stakes and zebra tape, besides other materials needed for the study, such as: annotation block, Canon powershot SX60HS 16.1MP digital camera LCD 3.0, 65x optical zoom, digital geoprocessing software (ArcMap, 2011, licensed the Laboratory of Digital Cartography, Geoprocessing and Remote Sensing - CADIGEOS, of the Postgraduate Courses of the Humanities Center of the Federal University of Campina Grande - UFCG). In addition, all botanical species were identified and numbered individually in ascending order, through an aluminum label with an identification number, and the use of a red ribbon for the same vegetable to be used in the later collections.

The variables of gas exchange of the plants that involve the processes of photosynthesis, transpiration and stomatal conductance, were measured using infrared gas analysis equipment, Infra Red Gas Analyzer (IRGA), called LCpro+ (from ADC BioScientific Ltda). Plant evaluations in both areas occurred between 8 and 10 a.m. in the morning. An artificial light source was coupled to LCpro+ to obtain a constancy of the photosynthetic photon flux density of $1200 \mu \mathrm{mol} . \mathrm{m}-2 . \mathrm{s}-1$.

In order to evaluate the changes in the structure and composition of the typical botanical species of Caatinga from the study areas, four collections were proposed during the year 2016. The readings with the LCpro+ were carried out on the plants that met the technical specifications at each sampling point, due to the limitation of the instrument in the analyzes in plants with very small leaf size.

In order to perform the readings, the leaves of the plants were completely expanded and not shaded, observing the following variables: stomatal conductance (GS) (mol.m-2.s-1), liquid photosynthesis (A) ( $\mu$ molm-2.s -1), transpiration (E) (mmolm-2.s-1) and internal CO2 concentration (Ci) ( $\mu$ mol.mol-1). The correlation between liquid photosynthesis $(A)$ and transpiration (E) yielded the water use efficiency (EUA) and the rubisco carboxylation efficiency (EiC) was obtained by A/Ci correlation (MACHADO et al. 2005; MELO et al., 2009).

Also used in this study was the SPAD-502, which is a portable meter from Minolta, to estimate the total chlorophyll content through SPAD indices, which measures the red light transmission at 650nm, when light absorption occurs by the chlorophyll molecule, and infrared light at 940nm, without absorption (MINOLTA, 1989). Based on these values the instrument calculates the SPAD (Soil Plant Analysis Development) index or value, which is highly correlated with the chlorophyll content.

For the purpose of recording the $\mathrm{Ci}, \mathrm{E}, \mathrm{GS}, \mathrm{A}, \mathrm{EUA}, \mathrm{EiC}$ in the LCprot the mean values of three tree leaves selected per sample species were taken into account, and for the estimation of the pigments in the SPAD, in three distinct tree leaves, the readings were evaluated through three replicates, the mean value being recorded for each species.

\section{Statistical analyzes}

The data were submitted to analysis of variance (ANOVA) and when a significant effect was found, the means obtained between the variables recorded in the equipment (SPAD and LCpro +) by the Tukey test, 
at a 5\% probability level, and to the linear regression model with the sum of squares analysis of type I and III, carried out from the software for statistical analysis XLStat (Freeware). In addition to the correlation and determination analyzes that were done with the Actionstat software (Pro Version).

\section{RESULTS}

Analysis of gas exchange and chlorophyll verification with botanical species of the areas were carried out in two periods (March and May 2016). Typically, the rainfall indexes for this period are characterized as, from medium to high for this region, thus enabling full metabolic activity of the plants. Due to the peculiarity of the vegetation of the Caatinga, in the second half of 2016, the collections for the months of August and November were not carried out in the two study areas, because in the dry season the plants lost their leaves. This fall was determined in loco, based on leafless branches and leaves fallen on the ground.

Therefore, most of the species were leafless or were in the final stages of senescence. In Table 1 are arranged the records made with the SPAD and with the LCpro+. To facilitate data arrangement, the trees searched were represented by numeric code. Area 1 was represented by points (P100 to P500) and area 2 represented by point (P600).

Table 1: middle values of SPAD, Cl, E, GS, A, EUA e EiC of the botanical species of the Caatinga.

\begin{tabular}{|c|c|c|c|c|c|c|c|c|c|c|}
\hline $\begin{array}{l}\text { Points/ } \\
\text { Distance } \\
\text { (m) }\end{array}$ & Coletas & Plants & SPAD & $\begin{array}{c}\mathrm{Cl} \\
\left(\mu \mathrm{mol} \mathrm{mol}{ }^{-1}\right)\end{array}$ & $\begin{array}{c}\mathrm{E}\left(\mathrm{mmol} . \mathrm{H}_{2} \mathrm{O} .\right. \\
\left.\mathrm{m}^{-2} \cdot \mathrm{s}^{-1}\right)\end{array}$ & $\begin{array}{c}\text { GS (mol.H2O. } \\
\left.m^{-2} . s^{-1}\right)\end{array}$ & $\begin{array}{c}\text { A }\left(\mu \mathrm{mol} . \mathrm{CO}_{2} .\right. \\
\left.\mathrm{m}^{-2} . \mathrm{s}^{-1}\right)\end{array}$ & $\begin{array}{c}\text { EUA (mol. } \\
\mathrm{H}_{2} \mathrm{O} . \\
\left.\mathrm{m}^{-2} . \mathrm{s}^{-1}\right)\end{array}$ & $\begin{array}{c}\text { EiC } \\
\text { (mmol m-2.s-1) }\end{array}$ & Hour \\
\hline 100 & 1 & 1 & 39 & 231.00 & 1.43 & 0.10 & 5.17 & 3.615 & 0.022 & $08: 25$ \\
\hline 100 & 2 & 1 & 41 & 201.67 & 1.92 & 0.17 & 8.82 & 4.594 & 0.044 & 08:02 \\
\hline 100 & 1 & 2 & 38 & 244.67 & 0.75 & 0.05 & 2.15 & 2.867 & 0.009 & $08: 35$ \\
\hline 100 & 2 & 2 & 32 & 203.33 & 3.16 & 0.24 & 11.62 & 3.677 & 0.057 & $08: 14$ \\
\hline 100 & 1 & 3 & 38 & 192.33 & 0.84 & 0.05 & 3.81 & 4.536 & 0.020 & $08: 42$ \\
\hline 100 & 2 & 3 & 40 & 210.67 & 2.24 & 0.12 & 6.25 & 2.790 & 0.030 & $08: 23$ \\
\hline 200 & 1 & 1 & 39 & 228.33 & 0.62 & 0.03 & 1.67 & 2.694 & 0.007 & $08: 53$ \\
\hline 200 & 2 & 1 & 37 & 252.67 & 1.85 & 0.10 & 4.10 & 2.216 & 0.016 & $08: 34$ \\
\hline 200 & 1 & 2 & 40 & 248.33 & 0.82 & 0.04 & 1.84 & 2.244 & 0.007 & $08: 56$ \\
\hline 200 & 2 & 2 & 39 & 231.67 & 2.05 & 1.29 & 5.76 & 2.810 & 0.025 & $08: 39$ \\
\hline 200 & 1 & 3 & 41 & 202.67 & 0.91 & 0.05 & 3.00 & 3.297 & 0.015 & 09:03 \\
\hline 200 & 2 & 3 & 37 & 245.67 & 2.21 & 0.17 & 7.16 & 3.240 & 0.029 & $08: 45$ \\
\hline 300 & 1 & 1 & 44 & 223.33 & 0.69 & 0.04 & 2.24 & 3.246 & 0.010 & 09:11 \\
\hline 300 & 2 & 1 & 50 & 241.00 & 1.73 & 0.11 & 5.90 & 3.410 & 0.024 & $08: 57$ \\
\hline 300 & 1 & 2 & 41 & 254.33 & 0.55 & 0.03 & 1.32 & 2.400 & 0.005 & $09: 15$ \\
\hline 300 & 2 & 2 & 41 & 254.67 & 2.16 & 0.15 & 4.90 & 2.269 & 0.019 & 09:04 \\
\hline 300 & 1 & 3 & 38 & 239.00 & 0.52 & 0.03 & 1.46 & 2.808 & 0.006 & $09: 26$ \\
\hline 300 & 2 & 3 & 35 & 247.33 & 2.44 & 0.18 & 6.40 & 2.623 & 0.026 & 09:06 \\
\hline 400 & 1 & 1 & 36 & 241.00 & 0.33 & 0.02 & 0.69 & 2.091 & 0.003 & 09:31 \\
\hline 400 & 2 & 1 & 39 & 248.00 & 2.33 & 0.19 & 6.20 & 2.661 & 0.025 & $09: 23$ \\
\hline 400 & 1 & 2 & 41 & 289.00 & 0.55 & 0.03 & 0.69 & 1.255 & 0.002 & $09: 40$ \\
\hline 400 & 2 & 2 & 44 & 236.00 & 1.81 & 0.13 & 5.21 & 2.878 & 0.022 & $09: 28$ \\
\hline 400 & 1 & 3 & 38 & 245.33 & 0.79 & 0.04 & 1.47 & 1.861 & 0.006 & $09: 45$ \\
\hline 400 & 2 & 3 & 41 & 246.00 & 2.20 & 0.17 & 6.04 & 2.745 & 0.025 & $09: 33$ \\
\hline 500 & 1 & 1 & 38 & 244.33 & 0.46 & 0.02 & 1.08 & 2.348 & 0.004 & $08: 00$ \\
\hline 500 & 2 & 1 & 41 & 230.67 & 1.72 & 0.10 & 4.52 & 2.628 & 0.020 & $09: 43$ \\
\hline 500 & 1 & 2 & 39 & 232.50 & 0.52 & 0.03 & 1.28 & 2.471 & 0.006 & $08: 15$ \\
\hline 500 & 2 & 2 & 41 & 199.67 & 1.72 & 0.09 & 6.49 & 3.773 & 0.033 & $09: 52$ \\
\hline 500 & 1 & 3 & 39 & 232.33 & 0.57 & 0.03 & 1.66 & 2.912 & 0.007 & $08: 25$ \\
\hline 500 & 2 & 3 & 42 & 224.00 & 1.55 & 0.08 & 4.40 & 2.839 & 0.020 & $09: 59$ \\
\hline 600 & 1 & 1 & 41.30 & 197.33 & 0.80 & 0.03 & 2.43 & 3.037 & 0.012 & $08: 25$ \\
\hline 600 & 2 & 1 & 42.20 & 274.00 & 1.49 & 0.14 & 3.62 & 2.430 & 0.013 & $08: 22$ \\
\hline 600 & 1 & 2 & 40.20 & 218.33 & 0.69 & 0.03 & 1.84 & 2.667 & 0.008 & $08: 32$ \\
\hline 600 & 2 & 2 & 43.23 & 236.33 & 1.96 & 0.20 & 7.76 & 3.960 & 0.033 & 08:31 \\
\hline 600 & 1 & 3 & 38.20 & 237.00 & 0.70 & 0.03 & 1.65 & 2.357 & 0.007 & $08: 38$ \\
\hline 600 & 2 & 3 & 43.36 & 218.33 & 2.30 & 0.26 & 11.00 & 4.783 & 0.050 & $08: 38$ \\
\hline 600 & 1 & 4 & 49.80 & 207.67 & 1.80 & 0.10 & 5.90 & 3.278 & 0.028 & $08: 45$ \\
\hline
\end{tabular}




\begin{tabular}{|l|l|l|l|l|l|l|l|l|l|l|}
\hline 600 & 2 & 4 & 49.20 & 261.00 & 2.32 & 0.27 & 6.76 & 2.914 & 0.026 & $08: 45$ \\
\hline 600 & 1 & 5 & 34.90 & 188.67 & 0.64 & 0.02 & 1.79 & 2.797 & 0.009 \\
\hline 600 & 2 & 5 & 40.90 & 265.67 & 3.10 & 0.42 & 7.92 & 2.555 & 0.030 \\
\hline 600 & 1 & 6 & 36.20 & 210.33 & 1.02 & 0.04 & 2.44 & 2.392 & 0.53 \\
\hline 600 & 2 & 6 & 47.23 & 256.67 & 3.44 & 0.46 & 10.10 & 2.936 & 0.039 \\
\hline 600 & 1 & 7 & 34.30 & 205.67 & 1.07 & 0.04 & 2.65 & 2.477 & 0.013 \\
\hline 600 & 2 & 7 & 36.23 & 257.00 & 3.35 & 0.42 & 9.47 & 2.827 & 0.037 \\
\hline 600 & 1 & 8 & 42.40 & 243.75 & 0.57 & 0.03 & 1.31 & 2.298 & 0.005 \\
\hline 600 & 2 & 8 & 44.10 & 271.00 & 1.41 & 0.14 & 3.58 & 2.539 & $09: 10$ \\
\hline 600 & 1 & 9 & 35.80 & 233.67 & 2.30 & 0.09 & 4.35 & 1.891 & 0.013 \\
\hline 600 & 2 & 9 & 36.50 & 243.00 & 2.99 & 0.31 & 9.47 & 3.167 & 0.019 \\
\hline
\end{tabular}

Subtitle: Planta 1 P100= Aspidosperma pyrifolium Mart.; Plant 2 P100= Aspidosperma pyrifolium Mart.; Plant 3 P100= Croton sonderianus; Plant 1 P200= Aspidosperma pyrifolium Mart.; Plant 2 P200= Aspidosperma pyrifolium Mart.; Plant 3 P200= Aspidosperma pyrifolium Mart.; Plant 1 P300= Aspidosperma pyrifolium Mart.; Plant 2 P300= Aspidosperma pyrifolium Mart.; Plant 3 P300= Aspidosperma pyrifolium Mart.; Plant 1 P400= Aspidosperma pyrifolium Mart.; Plant 2 P400= Aspidosperma pyrifolium Mart.; Plant 3 P400= Aspidosperma pyrifolium Mart.; Plant 1 P500= Aspidosperma pyrifolium Mart.; Plant 2 P500= Aspidosperma pyrifolium Mart.; Plant 3 P500= Aspidosperma pyrifolium Mart.; Plant 1 P600= Aspidosperma pyrifolium Mart.; Plant 2 P600= Croton sonderianus; Plant 3 P600= Croton sonderianus; Plant 4 P600= Croton sonderianus; Plant 5 P600= Croton sonderianus; Plant 6 P600= Croton sonderianus; Plant 7 P600=Croton sonderianus; Plant 8 P600 = Aspidosperma pyrifolium Mart.; Plant $9 \mathrm{P} 600=$ Ziziphus joazeiro.

It is noteworthy that at the point (P100) there are few tree species, apparently young and more exposed to solar radiation. By this point being closer to the Thermoelectric plants may be directly exposed to the air pollutants from their operation by burning fossil fuels (heavy oil HFO). Also, from point (P200 to P500) the physiognomy is shrub-tree and has similar characteristics for cover and density. The P600 point presents a less dense bushy-shrubby physiognomy.

In the use of the SPAD equipment, it was verified that the species with the highest SPAD value were Aspidosperma pyrifolium Mart., (SPAD $=50)$ P300, and Croton sonderianus $(\mathrm{SPAD}=49.20) \mathrm{P} 600$, both at the time of the second collection. The highest SPAD record in the first collection was for the species Croton sonderianus (SPAD $=49.80)$ P600. Most species $(60 \%)$ had higher SPAD values in the second collection. The SPAD values that were lower in the second collection compared to the first, occurred with the following plants and points: Plant 2 (P100); Plant 1 (P200); Plant 2 (P200); Plant 3 (P200); Plant 2 (P300); Plant 4 (P600).

A moderate positive correlation was observed between the two variables (Figure 2). The coefficient of correlation was $R=0.579$ and the coefficient of determination $R^{2}=0.335$, evidencing that only $33 \%$ of the variations of the SPAD measurements in the 2 nd collection are explained by the SPAD variations of the 1st collection.

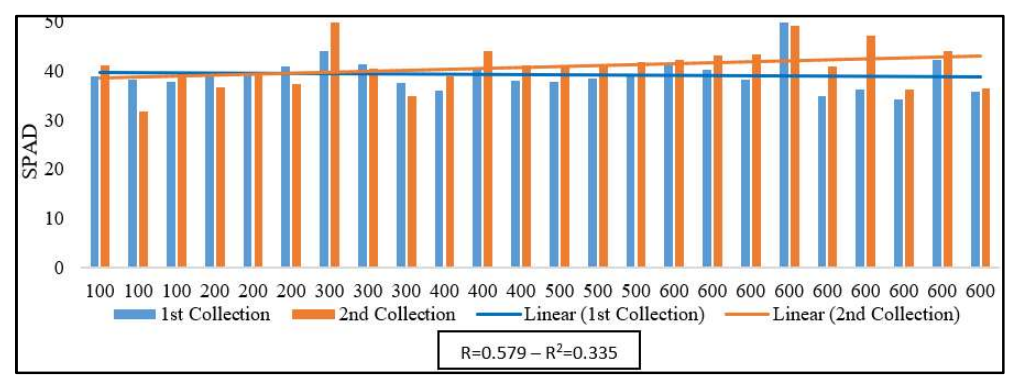

Figure 2: Spatial distribution of SPAD measures. Subtitle: $R=$ Coefficient of Correlation between SPAD (1st Collection) and (2nd Collection) $-\mathrm{R}^{2}=$ Determination Coefficient between SPAD (1st Collection) and (2nd Collection).

The maximum values of $E$ were recorded at points $(P 600)\left(E=3.44>335 \mathrm{mmol} \cdot \mathrm{H}_{2} \mathrm{O}_{\mathrm{m}} \mathrm{m}^{2} . \mathrm{s}^{-1}\right)$ and $(\mathrm{P} 100)$ $\left(\mathrm{E}=3.16 \mathrm{mmol} \cdot \mathrm{H}_{2} \mathrm{O} \cdot \mathrm{m}^{2}{ }^{2} \cdot \mathrm{s}^{-}\right)$, both second collection. In the first collection the highest recorded value was $\mathrm{E}=$ $2.30 \mathrm{mmol} . \mathrm{H}_{2} \mathrm{O} \cdot \mathrm{m}^{-2} \cdot \mathrm{s}^{-1}$ (P600), species Ziziphus joazeiro. In this path, it was verified that in all the species the values of $\mathrm{E}$ of the second collection were much bigger than in the first one. It is worth mentioning the tree species P400 (Aspidosperma pyrifolium Mart.), Which had the lowest rate of transpiration $(\mathrm{E}=$ 
$\left.0.33 \mathrm{mmol} \cdot \mathrm{H}_{2} \mathrm{O} \cdot \mathrm{m}^{-2} \cdot \mathrm{s}^{-}\right)$, seven times higher than in the second collection $\left(\mathrm{E}=2.33 \mathrm{mmol} \cdot \mathrm{H}_{2} \mathrm{O} \cdot \mathrm{m}^{-2} \cdot \mathrm{s}^{-1}\right)$. As for the spatial distribution of E measurements in the surveyed areas (Figure 3), it can be verified that there was a weak positive correlation between the two variables $(R=0.370693)$ and $\left.R^{2}=0.13741330024\right)$ of the 2 nd collection on the 1st collection.

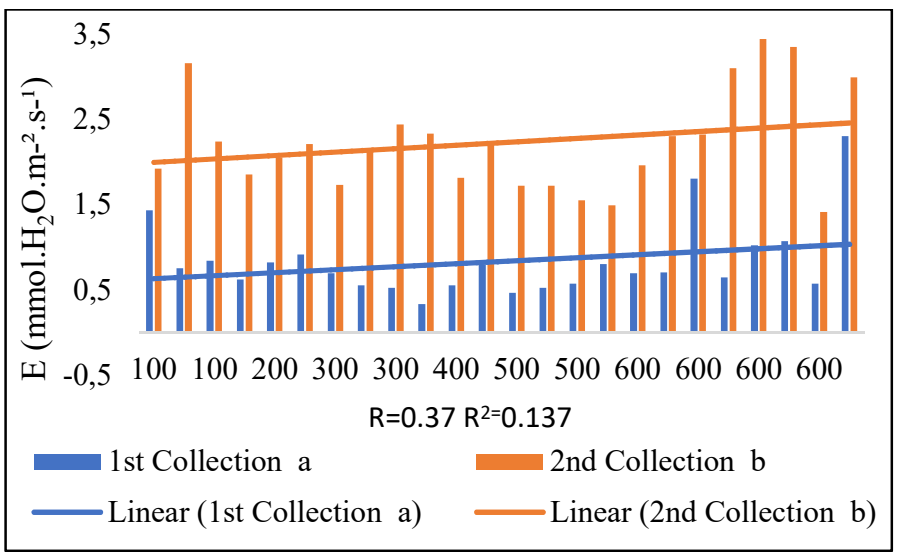

Figure 3: Spatial distribution of transpiration measurements. Subtitle: $\mathrm{R}=$ Coefficient of Correlation between $\mathrm{E}$ (1st Collection) and (2nd Collection); R2 = Coefficient of Determination between E (1st Collection) and (2nd Collection); $p=$ 7.13E-09.

Regarding the Tukey test, it was verified that the transpiration, of the tree species, were higher in the second collection, in this way the Confidence Interval $(a, b)$ were significantly different. The value of $p$ (7.13E-09) showed that there is only a $0.00000073 \%$ probability of observing a difference of 132,125 in the mean between groups under the null hypothesis.

GS is a physiological parameter where plants control the gas exchange, thus including the transpiration factor. Therefore, E and GS are both correlated with leaf water potential. In relation to the data presented in Table 1, it was verified that at point P200, species Aspidosperma pyrifolium Mart. was recorded the highest index (GS=1.29 mol. $\left.\mathrm{H}_{2} \mathrm{O} \cdot \mathrm{m}^{-}{ }^{2} . \mathrm{s}^{-}{ }^{1}\right)$, the remaining indexes were below $1 \mathrm{~mol} \cdot \mathrm{H}_{2} \mathrm{O} \cdot \mathrm{m}^{-}{ }^{2} . \mathrm{s}^{-}{ }^{1}$, with oscillation from 0.02 to $0.24 \mathrm{~mol}^{\mathrm{H}} \mathrm{H}_{2} \mathrm{O} \cdot \mathrm{m}^{-2} \cdot \mathrm{s}^{-1}$, and all indices in the second collection were higher. There is a direct correlation between $E$ and GS. Regarding the parameters $R$ and $R^{2}$ (figure 4), there was no correlation between the two variables $(R=0.074)$. Being, $R 2=0.005$ representing $0.55 \%$ interference from one variable over the other.

According to figure 5 , it can be observed that the values of A varied between $0.69<6.76 \mu$ mol. $\mathrm{CO}_{2} . \mathrm{m}$ ${ }^{2} . \mathrm{s}^{-1}$ (1st collection) and $3.58<11.62 \mu \mathrm{mol} \cdot \mathrm{CO}_{2} \cdot \mathrm{m}^{-2} \cdot \mathrm{s}^{-1}$ (2nd collection). Therefore, it was verified that the rates of the second collection were higher than those of the first one. The highest values were $(A=10.10,11.00$ and $\left.11.62 \mu \mathrm{mol} \cdot \mathrm{CO}_{2} \cdot \mathrm{m}^{-2} \cdot \mathrm{s}^{-1}\right)$, respectively, in Croton sonderianus, Croton sonderianus and Aspidosperma pyrifolium Mart. There was a negligible correlation between the two variables, $R=0.332$ and $R^{2}=0.110$, thus showing that $11 \%$ of the variations of the measurements of $A$ in the second collection are explained by the variations of the first one.

\footnotetext{
${ }^{1}$ As the Confidence Interval the probability was insignificant for all the parameters related to gas exchange, we chose to present only the Confidence Interval for Sweating, in order to reduce the amount of graphs in this study.
} 


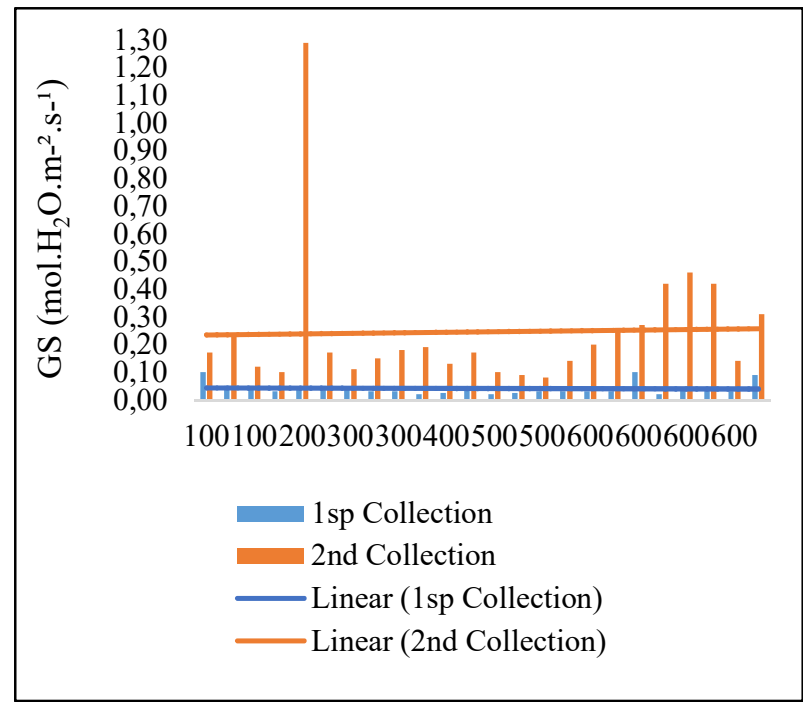

Figure 4: Spatial distribution of stomatal conductance measurements. Subtitle: $R=$ Coefficient of Correlation between GS (1st Collection) and (2nd Collection) - R2 = Coefficient of Determination between GS (1st Collection) and (2nd Collection).

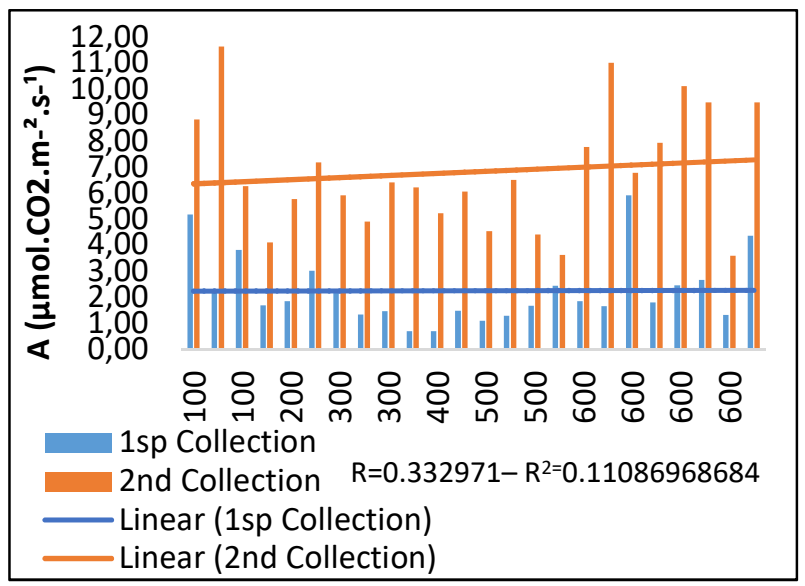

Figure 5: Spatial distribution of photosynthesis measurements. Note: $\mathrm{R}=$ Coefficient of Correlation between A (1st Collection) and (2nd Collection) - R2 = Coefficient of Determination between A (1st Collection) and (2nd Collection).

In terms of water use efficiency (US), the highest values were recorded at points $\mathrm{P} 600$ and P100 $\left(4,783>4,594\right.$ mol. $\left.\mathrm{H}_{2} \mathrm{O} \cdot \mathrm{m}^{-2} \cdot \mathrm{s}^{-1}\right)$ at the time of the second collection and at P100 $\left(4,536 \mathrm{~mol} \cdot \mathrm{H}_{2} \mathrm{O} \cdot \mathrm{m}^{-2} \cdot \mathrm{s}^{-}\right)$the tree species Croton sonderianus (first collection). In the analysis of $R$ and $R^{2}$ (figure 6 ), it can be seen that $R$ Pearson presented a negligible correlation between the two variables $(R=0.153)$ and $R^{2}=0.023$. Interfering in this way, with only $2.3 \%$ of one variable over the other.

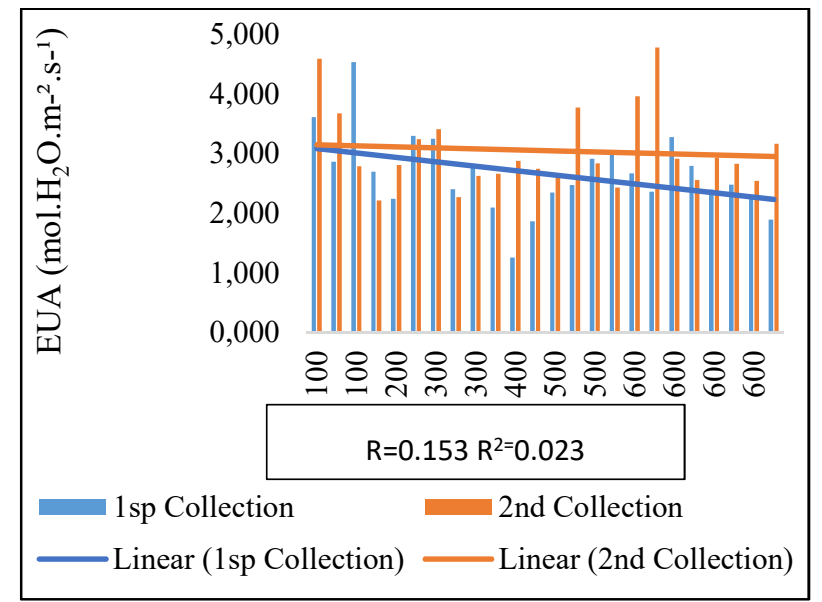

Figure 6: Spatial distribution of water use efficiency measures. Note: $\mathrm{R}=$ Coefficient of Correlation between USA (1st Collection) and (2nd Collection) $-\mathrm{R}^{2}=$ Coefficient of Determination between USA (1st Collection) and (2nd Collection).

For EiC, it was verified that tree species, Aspidosperma pyrifolium Mart., At point P100, obtained the highest value $\left(\mathrm{EiC}=0.057 \mu \mathrm{mol} \cdot \mathrm{m}^{-2} \cdot \mathrm{s}^{-1}\right)$, followed by Plant 3 , Croton sonderianus, at point P600 (EiC $=0.050$ $\left.\mu \mathrm{mol} . \mathrm{m}^{-2} \cdot \mathrm{s}^{-1}\right)$, both from the second collection. The highest index in the first collection was at point P600 $\left(\mathrm{EiC}=0.028 \mu \mathrm{mol} \cdot \mathrm{m}^{-2} . \mathrm{s}^{-1}\right)$, represented by Plant 4 , Croton sonderianus. It should also be noted that all indexes in the second collection were higher than the first.

A negligible correlation between the two variables, where $R=0.297$ and $R^{2}=0.088$, was observed, according to figure 7, thus giving a percentage of 8.87 of the variations of the Rubisco Carboxylation Efficiency 
measurements in the 2nd collection, explained by the variations Carboxylation Efficiency Rubisco of the 1st collection. It was also observed that the coefficients of determination of the trend lines of the graphs on the spatial distribution of the SPAD measurements and the gas exchanges, referring to figures $(2,3,4,5,6$ and 7), were still significant lower, when compared between the variables (1st and 2 nd collection).

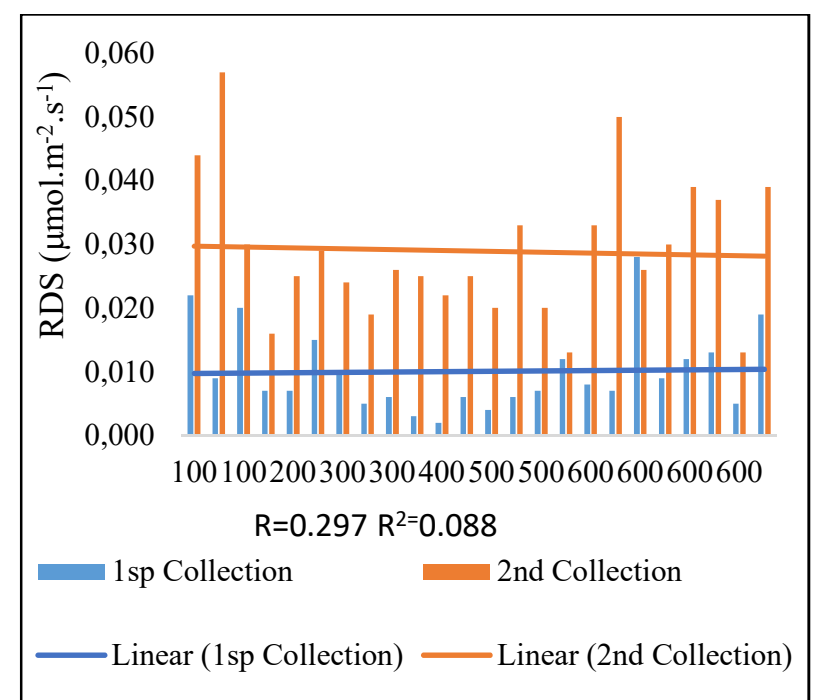

Figure 7: Spatial distribution of the measures of rubisco carboxylation efficiency. Note: $\mathrm{R}=$ Coefficient of Correlation between EiC (1st Collection) and (2nd Collection) - R2 = Coefficient of Determination between EiC (1st Collection) and (2nd Collection).

Therefore, as regards the estimation of chlorophyll, through the SPAD indices and the gas exchanges it was verified that it was not possible to associate interference of the Thermoelectric Plant Borborema S.A in the arboreal species of the surroundings. The cause of this may be related to the incidence of pollutants from Borborema S.A thermoelectric plant, in a different location from where this study was carried out, and/or the pollutant indices emitted by the UTE may be below the limit allowed by the atmospheric pollutant legislation.

As for the statistical data obtained in the evaluations of the two areas (A1 and A2) were submitted to a regression analysis, where it was verified that the coefficient of determination was $29 \%$ of the variability, of the dependent variable (Points), which was explained by the other 6 variables. Therefore, $R^{2}$ and adjusted $R^{2}$ were low. As for the $p$-value of the F-statistic calculated in the ANOVA table, taking into account the significance level of $5 \%$, the information brought by the explanatory variables was significantly better than a basic mean would bring (table 2).

Table 2: Analysis of variance regarding gas exchange in plants.

\begin{tabular}{|c|c|c|c|c|c|}
\hline Source & GL & Sum of squares & Average squares & F & Pr $>$ F \\
\hline Model & 6 & 471641.131 & 78606.855 & 2.825 & $\mathbf{0 . 0 2 1}$ \\
\hline Error & 41 & 1140858.869 & 27825.826 & - & - \\
\hline Total adjusted & 47 & 1612500.000 & - & - & - \\
\hline
\end{tabular}

Subtitle: Calculated against model $\mathrm{Y}=$ Mean $(\mathrm{Y})$

Based on the sum of squares of Type III (table 3) the variable Ci brings significant information to explain the variability of the dependent variable, collections. Regarding the variables E; GS; A; EUA and EiC, 
do not bring significant information to explain the variability of the dependent variable, collections. Thus, the explanatory variables, based on the sum of squares of Type III, the variable Ci was the most influential.

Table 3: Analysis of the sum of squares of type III (Collections).

\begin{tabular}{|c|c|c|c|c|c|}
\hline Source & GL & Sum of squares & Average squares & F & Pr $>$ F \\
\hline CI & 1 & 0.512 & 0.512 & 6.117 & $\mathbf{0 . 0 1 8}$ \\
\hline E & 1 & 0.283 & 0.283 & 3.381 & 0.073 \\
\hline GS & 1 & 0.041 & 0.041 & 0.492 & 0.487 \\
\hline A & 1 & 0.110 & 0.110 & 1.313 & 0.258 \\
\hline EUA & 1 & 0.161 & 0.161 & 1.918 & 0.174 \\
\hline EiC & 1 & 0.145 & 0.145 & 1.728 & 0.196 \\
\hline
\end{tabular}

\section{DISCUSSION}

The use of SPAD is an increasingly popular method for measuring chlorophyll concentration in plants (LING et al., 2011). In addition to being easy to operate, it provides an instant index of the photosynthetic capacity of the plant leaves (CAUDLE et al., 2014). In relation to the chlorophyll contents estimated by the SPAD index, in species of Jatropha curcas L., Moura et al. (2016), observed that in the 90-day period the plants submitted to the water deficit presented a significant increase in the concentration of photosynthetic pigments, with $60 \%$ of the pot capacity (CP), and in 120 days this index was $40 \%$. It was verified that the concentrations of photosynthetic pigments in the Jatropha curcas species presented resistance to the water deficit.

In order to select the most suitable tree species for the environmental conditions of the Kish Island in Iran, Haghighi et al. (2013), using a SPAD-502 chlorophyll meter from Minolta in seven species of plants, it can be observed in this study that there was a significant difference between the species, regarding the leaf chlorophyll content. Analyzing the rate of assimilation with respect to the $\mathrm{Ci}$ within the leaves, has been a useful approach to investigate plant responses to various environments. However, there are uncertainties in the calculation of $\mathrm{Ci}$ when stomata close (TOMINAGA et al., 2015).

Diverging from our study, regarding the reduction of $\mathrm{Ci}$ in Caatinga plants at different periods, Campelo et al. (2015), analyzing six tree species in irrigated and dry conditions in the region of Acaraú (CE), diagnosed that a reduction in the $\mathrm{Ci}$ of the species Swietenia macrophylla King occurred. and Handroanthus impetiginosa Mart., in the month of November of 2015, while for the species Calophyllum brasiliense Cambess, a reduction was observed in the months of November and February, and in the other species studied there was no influence of the water regime on the $\mathrm{Ci}$.

In another study, on the physiological variations of the Amazon forest canopy, in the municipality of Santarém (PA), Felsemburgh (2009), found that from $30^{\circ} \mathrm{C}$ to $\mathrm{Ci}$ in the substamatic chamber decreased considerably, with a reduction of up to $26 \%$ at $36^{\circ} \mathrm{C}$ and $32 \%$ at $42^{\circ} \mathrm{C}$. This fact may be related to the decrease of GS in high temperatures, which increases the resistance to $\mathrm{CO}_{2}$ entry and consequently causes a less diffusion of this, to the leaf mesophyll.

Thus, the reduction of the transpiration rate does not always represent the hydric stress, the closure of the stomata in the leaves is the strategy that plants use to maintain the turgescence during the period in which there is a greater demand of water vapor through the atmosphere (CARON et al, 2014). In general, 
with the closure of leaf stomata, the reduction of GS, $\mathrm{Ci}$ and the rate of $\mathrm{CO}_{2}$ assimilation (HASEGWA et al., 2000, MUSYIMI et al., 2007).

Thus, the reduction of the transpiration rate does not always represent the water stress, the closure of the stomata in the leaves is the strategy that plants use to maintain the turgescence during the period in which there is a greater demand of water vapor through the atmosphere (CARON et al, 2014). In general, with the closure of leaf stomata, the reduction of GS, $\mathrm{Ci}$ and the rate of $\mathrm{CO}_{2}$ assimilation (HASEGWA et al., 2000; MUSYIMI et al., 2007).

Regarding transpiration in adult trees, Mengistu et al. (2011), in a study in Ethiopia with Boswellia papyrifera specimens, in two areas: Metema (a relatively low altitude area, 810-990m), and in Abergelle (an area with altitude between 1400-1650m), verified that on the occasion of gas exchange in the Boswellia papyrifera, perspiration had increased from early morning to noon, mainly in response to increasing atmospheric water deficit and gradual stomatal closure. With the largest atmospheric hydric deficit resulted in a larger E and a smaller (US). They also observed that the E rate differed strongly between the two surveyed areas $(\mathrm{P}<0.001)$.

When comparing the GS among adult plants of the caatinga can be divergences between species of plants. Figueiredo et al. (2015), using ten adult individuals of Jatropha curcas L. and Jatropha mollissima (Pohl) Baill., in a study in Serra Talhada (PE), semiarid region of Northeast Brazil, observed that in relation to GS under low soil moisture (LSM) and high atmospheric water deficit (VPD) conditions, the specimens of Jatropha mollissima showed a reduction of the GS by $98 \%$, thus promoting a decrease in the assimilation and transpiration around $96 \%$, while the species J. curcas promoted a reduction of $66 \%$, leading to greater reductions in transpiration (75\%) than in assimilation (41\%).

It follows that the seasonality of the climatic elements inherent to a given region, such as air temperature, relative humidity and solar radiation can alter the physiological behavior of the plants, and consequently directly intervene in the growth and development, with about $90 \%$ of the biological production of these, occur by response to the photosynthetic activity and the increase in the stomatal diffusive resistance, thus causing a decrease in the liquid photosynthesis (FLOSS, 2004; AMARAL et al., 2006).

According to Otto et al. (2013), with the measurements of photosynthesis and stomatal conductance, it is possible to understand the effect of water availability on the growth of eucalyptus plantations. Thus, performing two experiments in two commercial areas (one wet the other dry) aimed at the exploration of cellulose, in the municipality of Eunápolis (BA), it can be verified that in the dry area the hydric deficit was a limiting factor for the stomatal opening and contributed to the decrease in carbon assimilation by photosynthesis $\left(A=1.2<3.4 \mu \mathrm{molm}^{2} \mathrm{~s}-1\right)$. The opposite occurred in the wet area, which presented greater stomatal control as a function of the vapor pressure deficit, and higher values of the photosynthetic rates (A $=12.5<16.4 \mu \mathrm{molm} \mathrm{m}^{2} \mathrm{~s}-1$ ) and productivity.

Therefore, the epidermis of the leaves of arid and semiarid species present numerous stomata that allow a higher rate of gas exchange during the relatively short periods of water supply, and stomata in depressions, which aid in the reduction of hydric loss (RAVEN et al., 2007). 
For Medeiros et al. (2017), the epicuticular waxes present in the leaves are the interface between the leaves and the atmosphere acting in the reduction of water loss. Investigating leaves of Aspidosperma pyrifolium, one of the most abundant in the Caatinga and semiarid region of Northeast Brazil, a marked difference was observed in the USA when compared to intact (control) leaf treatments, and leaves that had a mechanically removed leaf epicuticular (leaves without wax) between the years 2013 and 2014, being the highest reduction observed in $2013(P<0.05)$.

In relation to $\mathrm{EiC}$, in another study by Costa et al. (2015), in the municipality of Patos (PB), with specimens of aroeira (Myracrodruon urundeuva Allemão), observed that the carboxylation efficiency in these plants reduced markedly and progressively, under hydric deficit, as the period without irrigation advanced. As a result, there was a reduction in the carboxylation efficiency of the irrigated plants on the last day of hydric deficit, both in relation to the beginning of the treatments and in relation to the irrigated plants. It was further observed that recovery in the carboxylation efficiency was obtained only six days after rehydration.

Diverting from this study, Freitas et al. (2011), in a research on the effects of drip irrigation levels on three castor bean cultivars, found that there was a significant effect ( $F$ test, 1\% probability) of the irrigation slides on the variables dry mass of the petiole, (MSP), (GS), (A) and significant effect of cultivars on all studied variables, except for MSP. Therefore, there was interaction between the two studied factors, with significance for all variables, except for the variable leaf dry mass (MSL).

In another study, on gas exchange and photochemical efficiency of herbaceous cotton cultivars, performed at Embrapa Campina Grande, Ferraz et al. (2014), in order to establish reliability in the study, employed the analysis of variance by the $\mathrm{F}$ test, up to $5 \%$ probability of error. In addition to the regression model, for each variable, based on the significance of the regression coefficient (t-Student test) and the proportion of the variance explained by the equations of the models, given by the coefficient of determination $\left(R^{2}\right)$. They found that there were significant differences between the studied variables: rate $A$, Ci and GS ( $p<0.05)$.

As for the mixed model or type III, it is observed that it presents both fixed and random effects factors, besides the experimental error (random effect) and the population mean (fixed effect). Thus, it is prudent to quickly and efficiently evaluate and identify the best sum of squares to be used to test the hypotheses of interest, especially in mixed models, where the difficulties are generally greater (COIMBRA et al., 2006).

\section{CONCLUSIONS}

In the joint analysis of data on chlorophyll content and gas exchange with botanical species typical of the Caatinga in the two areas studied, allowed us to infer that: Due to loss of foliage, typical to the drought period in the semiarid region of Paraiba, it was not possible to perform gas exchange analysis and estimate the chlorophyll through SPAD indices of the selected plants in the two areas studied; The SPAD indices were 
higher at the second collection. However, there were no significant chlorophyll indices between the collections and the areas surveyed.

The $\mathrm{Cl}$ presented low variation between the two collection periods. It was thus evidenced, a noncorrelation between the collections and areas surveyed. In this way, even the indexes of $\mathrm{Ci}$, for the most part, were higher in the second collection, the highest register was in the first collection at point P400 with the species Aspidosperma pyrifolium Mart.; and For the other verified variables, in the gas exchanges, among the plants selected in this study, it was verified that there was no correlation and significant interference between the species of the two areas and between the collections. Statistically, these variables did not bring significant information, mainly, to explain the variability as the collection period.

\section{REFERENCES}

ALVES, E. S.; GIUSTI, P. M.; DOMINGOS, M.. Estudo anatômico foliar do clone híbrido 4430 de Trandescantia hibrid: alterações decorrentes da poluição aérea. Revista Brasileira de Botânica, p.24, p.561-566, 2001. DOI: http://dx.doi.org/10.1590/S0100-84042001000500012

AMARAL, J. A. T. D.; RENA, A. B.; AMARAL, J. F. T. D.. Crescimento vegetativo sazonal do cafeeiro e suas relações com fotoperíodo, frutificação, resistência estomática e fotossíntese. Pesquisa Agropecuária Brasileira, v.41, n.3, p.377-384, 2006. DOI: http://dx.doi.org/10.1590/S0100$\underline{204 \times 2006000300002}$

AZEVEDO, J. V. V.; SANTOS, A. C.; ALVES, T. L. B.; AZEVEDO P. V.; OLINDA, R. A.. Influência do clima na incidência de infecção respiratória aguda em crianças nos municípios de Campina Grande e Monteiro, Paraíba, Brasil. Revista Brasileira de Meteorologia, v.30, n.4, p.467-477, 2015. DOI: http://doi.org/10.1590/0102-778620140066

BALBINOT, R.; OLIVEIRA, N. K.; VANZETTO, S. C.; PEDROSO, K.; VALÉRIO, Á. F.. O papel da floresta no ciclo hidrológico em bacias hidrográficas. Ambiência, v.4, n.1, 2008.

BARROS, I. O.; SOARES, A. A.. Adaptações anatômicas em folhas de marmeleiro e velame da caatinga brasileira. Ciência Agronômica, v.44, n.1, p.192-198, 2013.

BELTRÃO, N. E. M.; OLIVEIRA, M. I. P.. Oleaginosas e seus óleos: vantagens e desvantagens para produção de biodiesel. Campina Grande: Embrapa, 2008.

CAMPELO, D. D. H.; LACERDA, C. F.; CORREIA, D.; BEZERRA, A.; ARAÚJO, J.; NEVES, A.; SOUSA, J. A.. Trocas gasosas e eficiência do fotossistema II em plantas adultas de seis espécies florestais em função do suprimento de água no solo. Árvore, Viçosa, v.39, n.5, p.973-983, 2015. DOI: http://doi.org/10.1590/0100-67622015000500020

CARON, B. O.; PERRANDO, E. R.; SCHMIDT, D.; MANFRON, P. A.; BEHLING, A.; ELLI, E. F.; ELOY, E.. Relações fisiológicas em mudas de pata-de-vaca (Bauhinia forficata Link). Revista Brasileira de Plantas Medicinais, Campinas, v.16, n.2, p.196201, 2014. DOI: http://doi.org/10.1590/S1516$\underline{05722014000200005}$
CAUDLE, K. L.; JOHNSON, L. C.; BAER, S. G.; MARICLE, B. R.. A comparison of seasonal foliar chlorophyll change among ecotypes and cultivars of Andropogon gerardii (Poaceae) by using nondestructive and destructive methods. Photosynthetica, v.52, n.4, p.511-518, 2014. DOI: http://doi.org/10.1007/s11099-014-0057-2

COIMBRA, J. L. M.; SOUZA, V. Q.; KOPP, M. M.; SILVA, J. G. C.; OLIVEIRA, A. C.; CARVALHO, F. I. F.. Esperanças matemáticas dos quadrados médios: uma análise essencial. Ciência Rural, Santa Maria, v.36, n.6, p.1730-1738, 2006. DOI: http://doi.org/10.1590/S0103-84782006000600010

COSTA, A. S.; FREIRE, A. L. O.; BAKKE, I. A.; PEREIRA, F. H. F.. Respostas fisiológicas e bioquímicas de plantas de aroeira (Myracrodruon urundeuva allemão) ao déficit hídrico e posterior recuperação. Irriga, Botucatu, v.20, n.4, p.705-717, 2015. DOI: https://doi.org/10.15809/irriga.2015v20n4p705

COSTA, C. C. D. A.; CAMACHO, R. G. V.; MACEDO, I. D. D.; SILVA, P. C. M. D.. Análise comparativa da produção de serapilheira em fragmentos arbóreos e arbustivos em área de caatinga na flona de Açu-RN. Árvore, Viçosa, v.34, n.2, p.259-265, 2010

COSTA, G. F.; MARENCO, R. A.. Fotossíntese, condutância estomática e potencial hídrico foliar em árvores jovens de andiroba (Carapa guianensis). Acta Amazonica, v.37, n.2, p.229-234, 2007.

FELSEMBURGH, C. A.. Respostas fotossintéticas à variação da temperatura foliar do dossel na Flona do Tapajós-PA. Tese (Doutorado em Ecologia Aplicada) - Universidade de São Paulo, Piracicaba, 2009.

FERRAZ, R. L. D. S.; BELTRAO, N. E. D. M.; MELO, A. S. D.; MAGALHAES, I. D.; FERNANDES, P. D.; ROCHA, M. D. S.. Trocas gasosas e eficiência fotoquímica de cultivares de algodoeiro herbáceo sob aplicação de silício foliar. Semina: Ciências Agrárias, Londrina, v.35, n.2, p.735-748, 2014. DOI: http://doi.org/10.5433/1679-0359.2014v35n2p735

FIGUEIREDO, K. V.; OLIVEIRA, M. T.; ARRUDA, E. C.; SILVA, B. C.; SANTOS, M. G.. Changes in leaf epicuticular wax, gas exchange and biochemistry metabolism between Jatropha mollissima and Jatropha curcas under semiarid conditions. 
Acta Physiologiae Plantarum, v.37, n.108, 2015. DOI: http://doi.org/10.1007/s11738-015-1855-2

FLOSS, E. L.. Fisiologia das plantas cultivadas. Passo Fundo: UPF, 2004.

FREITAS, C. A.; SILVA, A. R.; BEZERRA, F. M.; LACERDA, C. F. D.; PEREIRA FILHO, J. V.; SOUSA, G. G, C. A. S.. Produção de matéria seca e trocas gasosas em cultivares de mamoneira sob níveis de irrigação. Revista Brasileira de Engenharia Agrícola Ambiental, v.15, n.11, p.1168-1174, 2011.

GRANJA, J. A. A.. Adaptações morfofisiológicas de Croton blanchetianus Bail em condições de semiárido

Pernambucano. Mestrado (Dissertação em Biologia Vegetal) - Universidade Federal de Pernambuco, Recife, 2013.

HAGHIGHI, N. Z.; SALEHI, H.. Comparison between the growth and development of some cultured plants among different regions of Kish Island. Journal of Central European Agriculture, v.14, n.2, p.86-98, 2013. DOI: http://doi.org/10.5513/JCEA01/14.2.1238

HASEGAWA, P. M.; BRESSAN, R. A.; ZHU, J. K.; BOHNERT, H. J.. Plant cellular and molecular responses to high salinity. Annual Review Plant Molecular Biology, New York, v.51, p.463-499, 2000.

INTO, M. S. C.; CAVALCANTE, M. A. B.; ANDRADE, M. V. M.. Potencial forrageiro da caatinga, fenologia, métodos de avaliação da área foliar e o efeito do déficit hídrico sobre o crescimento de plantas. Revista Electrónica de Veterinária, v.7, n.4, 2006.

JÚNIOR, M. Z. A.; ALMEIDA LOBO, F.; DALMAGRO, H. J.; VOURLITIS, G. L.; ORTIZ, C. E. R.; DALMOLIN, Â. C.; SULI, G. S.. Efeito do microclima no intercâmbio gasoso potencial de cambará (Vochysia divergens Pohl) e lixeira (Curatella americana L.) em área de Cerrado. Revista Brasileira de Biociências, Porto Alegre, v.9, n.1, p.77-85, 2011.

LING, Q. H.; HUANG, W. H.; JARVIS, P.. Use of a SPAD-502 meter to measure leaf chlorophyll concentration in Arabidopsis thaliana. Photosynthesis Research, n.107, p.209-214, 2011. DOI: http://doi.org/10.1007/s11120-010$\underline{9606-0}$

MACEDO, M. J. H.; GUEDES, R. V. S.; SOUSA, F. A. S.. Monitoramento e intensidade das secas e chuvas na cidade de Campina Grande/PB. Revista Brasileira de Climatologia, v.7, 2011. DOI: http://doi.org/10.5380/abclima.v8i0.25797

MACHADO, E. C.; SCHMIDT, P. T.; MEDINA, C. L.; RIBEIRO, R. V.. Respostas da fotossíntese de três espécies de citros a fatores ambientais. Pesquisa Agropecuária Brasileira, Brasília, v.40, n.12, p.1161- 1170, 2005.

MEDEIROS, C. D.; FALCÃO, H. M.; ALMEIDA-CORTEZ, J.; SANTOS, D. Y. A. C.; OLIVEIRA, A. F. M.; SANTOS, M. G.. Leaf epicuticular wax content changes under different rainfall regimes, and its removal affects the leaf chlorophyll content and gas exchanges of Aspidosperma pyrifolium in a seasonally dry tropical forest. South African Journal of Botany, v.111, p.267-274, 2017. DOI: https://doi.org/10.1016/i.saib.2017.03.033
MELO, A. S. D.; SILVA JÚNIOR, C. D.; FERNANDES, P. D.; SOBRAL, L. F.; BRITO, M. E. B.; PAULA, J. D. M. D. D.. Alterações das características fisiológicas da bananeira sob condições de fertirrigação. Ciência Rural, Santa Maria, v.39, n.3, p.733-741, 2009.

MENDONÇA, L. A.; FRISCHKORN, H.; SANTIAGO, M. F.; CAMARGO, P. B. D.; LIMA, J. O.; MENDES FILHO, J.. Identificação de mudanças florestais por $13 \mathrm{C}$ e $15 \mathrm{~N}$ dos solos da Chapada do Araripe, Ceará. Revista Brasileira de Engenharia Agrícola e Ambiental, v.14, n.3, p.314-319, 2010. DOI: http://doi.org/10.1590/S1415$\underline{43662010000300012}$

MENGISTU, T.; STERCK, F. J.; FETENE, M.; TADESSE, W.; BONGERS, F.. Leaf gas exchange in the frankincense tree (Boswellia papyrifera) of African dry woodlands. Tree Physiology, n.31, p.740-750, 2011. DOI: https://doi.org/10.1093/treephys/tpr067

MINOLTA. Konica Minolta Ltda. Manual for chlorophyll meter SPAD 502. Osaka: Minolta 1989.

MOURA, A. R.; NOGUEIRA, R. J. M. C.; SILVA, J. A. A.; LIMA, T. V.. Relações hídricas e solutos orgânicos em plantas jovens de Jatropha curcas L. sob diferentes regimes hídricos. Ciência Florestal, Santa Maria, v.26, n.2, p.345-354, 2016. DOI: http://doi.org/10.5902/1980509822735

MUSYIMI, D. M.; NETONDO, G. W.; OUMA, G.. Effects of salinity on gas exchange and nutrients uptake in avocados. Journal of Biological Sciences, v.7, n.3, p.496-505, 2007. DOI: http://doi.org/10.3923/jbs.2007.496.505

NOBRE, P.; OYAMA, M. D.; OLIVEIRA, G. S.; TOMASELLA, J.. Impactos de mudanças climáticas globais na hidrologia do semiárido do Nordeste brasileiro para o final do século XXI. Campina Grande: INSA, 2011.

OLIVEIRA, L. L.; COSTA, R. F. D.; ASSIS, S. F.; COSTA, A. C. L.; BRAGA, A. P.. Precipitação efetiva e interceptação em Caxiuanã, na Amazônia Oriental. Acta Amazônica, Manaus, v.38, n.4, p.723-732, 2008. DOI:

http://doi.org/10.1590/S0044-59672008000400016

OTTO, M. S. G.; VERGANI, A. R.; GONÇALVES, A. N.; VRECHI, A.; SILVA, S. R.; STAPE, J. L.. Fotossíntese, condutância estomática e produtividade de clones de eucalyptus sob diferentes condições edafoclimáticas. Árvore, Viçosa, v.36, n.3, p.431-439, 2013.

QUEIROZ, A. T.; OLIVEIRA, L. A. Relação entre produção e demanda hídrica na bacia do Rio Uberabinha, estado de Minas Gerais, Brasil. Sociedade \& Natureza, Uberlândia, v.25, n.1, p.191-204, 2013. DOI:

http://doi.org/10.1590/S1982-45132013000100015

RAVEN, P. H.; EVERT, R. F.; EICHHORN, S. E.. Biologia vegetal. 7 ed. Rio de Janeiro: Guanabara Koogan, 2007.

SOUZA, M. J. N.; OLIVEIRA, V. P. V.. Os enclaves úmidos e sub-úmidos do semiárido do nordeste brasileiro. Mercator: Revista de Geografia da UFC, v.5, n.9, 2006.

TOMINAGA, J.; KAWAMITSU, Y.. Cuticle Affects Calculations of Internal $\mathrm{CO}_{2}$ in Leaves Closing Their Stomata. Plant and 
Cell Physiology, v.56, n.10, p.1900-1908, 2015. DOI: http://doi.org/10.1093/pcp/pcv109
WALTER, L. C.; ROSA, H. T.; STRECK, N. A.. Mecanismos de aclimatação das plantas à elevada concentração de $\mathrm{CO}_{2}$. Ciência Rural, v.45, n.9, 2015. DOI: http://doi.org/10.1590/0103-8478cr20140527

A CBPC - Companhia Brasileira de Produção Científica (CNPJ: 11.221.422/0001-03) detém os direitos materiais desta publicação. Os direitos referem-se à publicação do trabalho em qualquer parte do mundo, incluindo os direitos às renovações, expansões e disseminações da contribuição, bem como outros direitos subsidiários. Todos os trabalhos publicados eletronicamente poderão posteriormente ser publicados em coletâneas impressas sob coordenação da Sustenere Publishing, da Companhia Brasileira de Produção Científica e seus parceiros autorizados. Os (as) autores (as) preservam os direitos autorais, mas não têm permissão para a publicação da contribuição em outro meio, impresso ou digital, em português ou em tradução. 